\title{
The Effect of Temperature on the Metabolism of Baker's Yeast growing on Continuous Culture
}

\author{
By R. C. JONES* AND J. S. HOUGH \\ Department of Biochemistry, University of Birmingham
}

(Accepted for publication ro October 1969)

\begin{abstract}
SUMMARY
Glucose-limited cultures of baker's yeast growing at $25^{\circ}$ had a maximum growth rate, saturation constant and yield constant of $0.22 \mathrm{hr}^{-1}, \mathrm{I} 29 \mu \mathrm{g} . / \mathrm{ml}$. and 0.225 , respectively, whereas when growing at $38^{\circ}$ the corresponding values were $0.25 \mathrm{hr}^{-1}, 300 \mu \mathrm{g}$. $/ \mathrm{ml}$. and 0.204 . In continuous culture, with the dilution rate fixed at $\mathrm{O}^{\cdot} \mathrm{I} \mathrm{hr}^{-1}$ there were no differences observed in viability, incidence of respiratory deficient mutants, cytochrome spectra or mean cell dry weights, between cultures grown at 25 and $38^{\circ}$. The culture grown at $25^{\circ}$ had a smaller mean cell volume, greater yield value and nitrogen utilization. Ethanol, pyruvate and $\alpha$-ketoglutarate were secreted to a greater degree in cultures grown at $38^{\circ}$. Yeast grown at $25^{\circ}$ had a smaller capacity to produce carbon dioxide but greater ability to take up oxygen. Enzymes associated with glycolysis, alcohol production, tricarboxylic acid cycle and respiratory chain in organisms cultured continuously at 25 and $38^{\circ}$ showed few important differences. The most obvious ones were those involving $\alpha$-ketoglutarate as a substrate, especially $\alpha$-ketoglutarate dehydrogenase. There were only small differences in adenosine phosphates and nicotinamide nucleotides. At $25^{\circ}$ the ratio NAD/NADH was $1 \cdot 5$ but for organisms grown at $38^{\circ}$ the ratio was $\mathrm{I} \cdot \mathrm{I}$.
\end{abstract}

\section{INTRODUCTION}

The growth and metabolic activities of micro-organisms are profoundly affected by the temperature at which they grow. For example, with Saccharomyces it has long been known that the rate of alcohol production increases with temperature up to $40^{\circ}$ (Brown, 1914). Again fusel alcohol production is stimulated by increasing temperature with top-fermenting yeasts but not with bottom-fermenting yeasts (Hough \& Stevens, 196I) and Wolter, Lietz \& Beubler (1966) showed an increase in ethyl acetate production with increases in incubation temperature.

There are many reports that the synthesis of enzymes are affected by the growth temperature (Knox, 1955). Christopherson (1967) demonstrated with Candida pseudotropicalis that the activity of glucose-6-phosphate dehydrogenase was lower when grown at $37^{\circ}$ than when grown at $20^{\circ}$. In a similar experiment the alcohol dehydrogenase activity of Saccharomyces cerevisiae was two- to three-fold different between organisms grown at 15 and $37^{\circ}$. The induction of the enzyme catalase in S. cerevisiae also has been reported to be temperature sensitive (Sulebele \& Rege, 1967).

In continuous culture the metabolic activities of a micro-organism vary with growth rate. Thus Tempest \& Herbert (1965) demonstrated with glucose-limited continuous

\footnotetext{
* Present address: The Distillers Co. Ltd. Menstrie, Clackmannan.
} 
cultures of Candida utilis that growth rate markedly affected respiration rate. But the growth rate in batch culture varies with temperature and thus there is always doubt as to whether reported effects of temperature on metabolism are direct or arise from an alteration in growth rate. An assessment of the effect of culture temperature on the metabolism of a micro-organism, therefore, is best carried out under conditions where the growth rate is constant and independent of temperature. This is readily achieved with continuous culture.

In the present study, a detailed comparison of the metabolism of baker's yeast has been carried out with continuous cultures maintained at 25 and at $38^{\circ}$, but with the rate of growth kept constant. The object was to obtain information which would explain why, at higher temperatures of cultivation, cell production is decreased but the rate of ethanol production is enhanced (Hough \& Rudin, 1958).

\section{METHODS}

Organism and media. The yeast used was a strain of Saccharomyces cerevisiae isolated from a commercial sample of baker's yeast and employed in earlier studies (Brown \& Hough, I965, 1966). It was maintained on a solidified malt extract medium (Wickerham, I95I) and subcultured monthly. For experimental work the liquid synthetic medium of Cutts \& Rainbow (1950) was modified in that the lactate buffer was replaced by citric acid monohydrate $(\mathrm{I} \cdot \mathrm{I} 3 \mathrm{~g}$./l.) plus trisodium citrate dihydrate (4.44 g./1.).

Culture conditions. Batch cultures $(50 \mathrm{ml}$.) were grown in $150 \mathrm{ml}$. conical flasks in a thermostatically-controlled incubator at temperatures from 25 to $40^{\circ}$. The flasks were shaken at 100 strokes/min. with an amplitude of $4.5 \mathrm{~cm}$. Continuous cultures were established in a single-stage glass culture vessel of $150 \mathrm{ml}$. working volume. The dilution rate was controlled, generally at $0 \cdot \mathrm{I} \mathrm{hr}^{-1}$ (equivalent to a residence time of Io $\mathrm{hr}$ ) using a peristaltic metering pump and the temperature regulated by pumping water from a thermostatically-controlled water-bath through a jacket surrounding the vessel. Filtered sterilized air was injected below liquid level in the vessel, at a rate of $50 \mathrm{ml} . / \mathrm{min}$. This procedure gave reasonably high levels of dissolved oxygen, indicated by similar yields when various oxygen and air mixtures at the same flow rates were used. The culture was inoculated and sampled by means of a device described by Heatley (1950). When the culture optical density (measured at $625 \mathrm{~nm}$., using a Unicam SP 500 spectrophotometer) was constant for 3 days, equilibrium was established and samples taken for detailed analyses.

Growth constants. Yeast, previously grown in glucose-limited continuous culture, was inoculated into shake flasks containing a complete medium but with glucose concentration ranging from $0 \cdot 1$ to $10 \mathrm{mg}$. $/ \mathrm{ml}$. In each series of experiments the inoculum yeast was grown at a corresponding temperature. Readings of absorbance, at $625 \mathrm{~nm}$., were taken at short intervals during early stages of growth of the yeast Results were calculated from the ratio of $\log _{2}$ O.D. to time.

Viability measurements. Both a staining method (Lindegren, 1949) and slide-culture technique (Gilliland, 1959) were employed.

Respiratory-deficient mutants. The method of Ogur, St. John \& Nagai (1957) was used for detection of the respiratory deficient organisms.

Distribution of yeast cell sizes. Organisms suspended in sodium chloride solution 
$(0.9 \%)$, containing maltose $(10 \%)$ to minimize aggregation, were examined in a Coulter electronic particle counter fitted with $70 \mu \mathrm{m}$. orifice.

Growth factor requirements. These were determined by the method of Shultz \& Atkin (1947).

Manometry. Organisms were separated from the cultures by centrifugation washed with citrate buffer $(50 \mathrm{~mm})$ plus potassium dihydrogen phosphate $(5 \mathrm{~mm})$ at $\mathrm{pH} 5.0$ and resuspended in the same buffer solution at a known concentration of about $2 \mathrm{mg}$. $/ \mathrm{ml}$. Oxygen uptake and carbon dioxide output under aerobic conditions were measured using a Braun Rotary Warburg Manometer.

Samples for analyses. Samples were transferred to ice-cooled tubes and centrifuged ( $3000 \mathrm{~g}$ for $3 \mathrm{~min}$.) at $2^{\circ}$. The samples for cytochrome spectra and assays of enzyme and coenzyme estimations were then treated as indicated below. For all other analyses, the yeast pellets were washed with water $\left(\right.$ at $2^{\circ}$ ) and then dried under reduced pressure until of constant weight. They were then stored until required in a desiccator (at $4^{\circ}$ ).

Cytochrome spectra. The method of Linnane, Biggs, Huang \& Clark-Walker (I968) was used.

Table I. List of enzymes and coenzymes investigated

Enzyme or coenzyme

Phosphofructokinase

Pyruvate kinase

Pyruvate dehydrogenase enzyme system

Pyruvate decarboxylase

Alcohol dehydrogenase

Aconitate hydratase

Isocitrate dehydrogenase (NAD specific)

Isocitrate dehydrogenase (NADP specific)

Ketoglutarate dehydrogenase enzyme system

Succinate dehydrogenase

Fumarate hydratase

Malate dehydrogenase

NADH oxidase enzyme system

$\mathrm{NADH}$ : cytochrome- $c$ oxidoreductase

Cytochrome- $c$ : oxygen oxidoreductase

Succinate: cytochrome- $c$ oxidoreductase

Glutamate:NAD oxidoreductase

Glutamate: NADP oxidoreductase

Aspartate:ketoglutarate aminotransferase
E.C. number

2.7.I.II.

2.7 .1 .40

-

4.I.I.I.

I.I.I.I.

4.2.1.3.

I . I . I . 4 I .

I I . I . 42

-

I.3.99. I .

4.2.1.2.

I. I . I. 37 .

$$
\text { - }
$$

I.6.2.I.

I.9.3.I.

-

I . $4, \mathrm{I} \cdot 2 / 3$.

I.4. I.3/4.

2.6. I. I .
Reference for assay

Viñuela, Sales \& Sols, 1963

Rose, 1960

Alvarez, Vanderwinkel \& Wiame, 1958

Holzer \& Goedde, 1957

Bücher \& Redetzki, I95I

Racker, I950

Kornberg, I955a

Kornberg, $1955 b$

Holzer, Hierholzer \& Witt, 1963

Hauber \& Singer, 1967

Racker, 1950

Bergmeyer, 1963

Green \& Ziegler, 1963

Polakis, Bartley \& Meek, 1964

Polakis, Bartley \& Meek, I964

Mackler et al. 1962

Holzer \& Schneider, 1957

Holzer \& Schneider, 1957

Holzer, Gerlach, Jacobi \&

Gnoth, I958

Bergmeyer, I963

Bergmeyer, 1963

Polakis \& Bartley, 1965

ATP, ADP, AMP
NAD

NADH

Assays for enzyme and coenzyme estimations. Yeast samples (I00 to $200 \mathrm{mg}$. dry weight) were washed twice with $50 \mathrm{~mm}$-potassium phosphate buffer $\left(\mathrm{pH}_{7}{ }^{\circ}\right)$, resuspended in $6 \mathrm{ml}$. of this buffer and disintegrated in a Mickle tissue disintegrator ( 15 min. using I mm. diam. glass beads). After centrifugation (Io min. at $3000 \mathrm{~g}, 2^{\circ}$ ) the clear supernatant fraction contained the soluble enzymes and enzymes of the mitochondria which were then assayed immediately. All stages in the extraction were carried out at $2^{\circ}$. The assays used are given in Table I. Protein was estimated by the Folin-Lowry method (Lowry, Rosebrough, Farr \& Randall, I95I).

Keto-acids. Pyruvate and $\alpha$-ketoglutarate were estimated enzymically by the methods described by Bergmeyer (I963). 


\section{RESULTS}

\section{The effect of temperature on the growth characteristics of Saccharomyces cerevisiae}

The growth factor requirements of this yeast when growing at $25^{\circ}$ or at $38^{\circ}$ were identical. There was an absolute requirement for biotin, pantothenate, inositol and pyridoxine and a partial requirement for nicotinic acid and thiamine. Comparison of growth constants of yeast cultured at 25 and $38^{\circ}$ are, therefore, not complicated by any changes in growth factor requirements. The saturation constants $\left(K_{s}\right)$ and max. growth rates $\left(\mu_{\max }\right)$ for glucose-limited cultures at these temperatures were calculated from experimental results obtained with batch cultures containing a range of glucose concentrations (Herbert, Elsworth \& Telling, I956). For cultures incubated at $25^{\circ}$ the $\mu_{\max }$ value was $0.22 \mathrm{hr}^{-1}$ and $K_{s}$ value $129 \mu \mathrm{g} . / \mathrm{ml}$. whereas for cultures incubated at $38^{\circ}$, $\mu_{\max }$ was $0.25 \mathrm{hr}^{-1}$ and $K_{s}$ equal to $300 \mu \mathrm{g}$. $/ \mathrm{ml}$. (Fig. I). The yield constants for these cultures grown at 25 and $38^{\circ}$ were 0.225 and 0.204 , respectively.

Table 2. Growth characteristics of $S$. cerevisiae

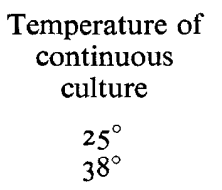

$\begin{array}{cccc}\begin{array}{c}\text { Gell } \\ \text { Glucose }\end{array} & \begin{array}{c}\text { Ethanol } \\ \text { produced }\end{array} & \begin{array}{c}\text { Nitrogen } \\ \text { utilized (\%) }\end{array} \\ \text { utilized (\%) } & \text { mg./ml. medium } & \mu \mathrm{g} . / \mathrm{mg} \text {. yeasts } & \\ \text { 100 } & 3.2 & 193 & 4 \mathbf{I} \\ 99 & 2 \cdot 6 & 468 & 37\end{array}$

The viability of the yeast populations were measured over a range of dilution rates from 0.07 to $0.20 \mathrm{hr}^{-1}$ when growing in a glucose-limited chemostat. With the growth temperature at $25^{\circ}$ the percentage of viable cells ranged from 92 to 98 , while with cultures maintained at $38^{\circ}$, viability varied from 90 to 98 . The incidence of respiratory deficient mutants was less than $0.2 \%$ irrespective of the growth temperatures and, therefore, like viability could be ignored when interpreting subsequent results.

Again, the cytochrome spectra of organisms grown continuously (glucose-limited, $D=0 \cdot \mathrm{I} \mathrm{hr}^{-1}$ ) were similar and showed peaks at 524, 530, 55I, 562 and $600 \mathrm{~nm}$. These probably were due to the presence of cytochromes $c+c_{1}, b+b_{2}$ and $a+a_{3}$ respectively. There was a difference, however, between the cultures grown at 25 and $38^{\circ}$ with respect to their mean cell volumes; organisms grown at $38^{\circ}$ were slightly larger than those grown at $25^{\circ}$ although their mean cell dry weights were identical.

Cultures grown at 25 and $38^{\circ}$ in a glucose-limited medium $\left(D=0 . \mathrm{I} \mathrm{hr}^{-1}\right)$ were found to differ in several respects (Table 2). The yield of organisms was greater at the lower growth temperature and slightly more nitrogen was utilized. In contrast, the ethanol production was less than half that observed with cultures grown at $38^{\circ}$, despite the complete utilization of glucose.

A further difference was the higher levels of $\alpha$-keto acids excreted into the medium by cultures grown continuously at $38^{\circ}$. The steady state levels of the pyruvate and $\alpha$-ketoglutarate attained in glucose-limited $\left(D=0 . \mathrm{I} \mathrm{hr}^{-1}\right)$ when the temperature was varied from 20 to $42^{\circ}$ are shown in continuous culture (Fig. 2). The level of $\alpha$-ketoglutarate was higher than that of pyruvate at all temperatures below $40^{\circ}$. Between the growth temperature of 30 and $35^{\circ}$ the level of $\alpha$-ketoglutarate in the medium rose from 3 to I I $\mu \mathrm{g}$. $/ \mathrm{ml}$. At $35^{\circ}$ the rate of excretion of $\alpha$-ketoglutarate was maximal. At higher temperatures the level of pyruvate in the medium rose sharply and at $4 \mathrm{I}^{\circ}$ 
exceeded I50 $\mu \mathrm{g} . / \mathrm{ml}$. Other metabolities of the tricarboxylic acid cycle (malate, oxaloacetate and isocitrate) could not be detected in the medium, nor were amino acids, fatty acids and lactic acid excreted.

Respiratory activities. Manometric studies were carried out in order to examine the effect of various growth temperatures upon the respiratory activities of the yeast. In one experiment, the growth-limiting substrate was glucose (I0 mg./1.) and in another DL-lactate (I $5 \mathrm{mg}$./1.). The dilution rate was held constant $\left(\mathrm{O} \cdot \mathrm{I} \mathrm{hr}^{-1}\right)$ and the temperature raised progressively in small steps from 25 to $39^{\circ}$. Organisms were removed

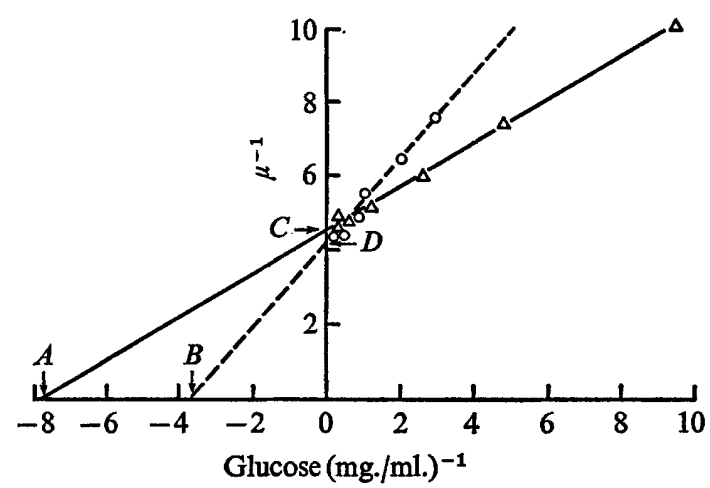

Fig. I

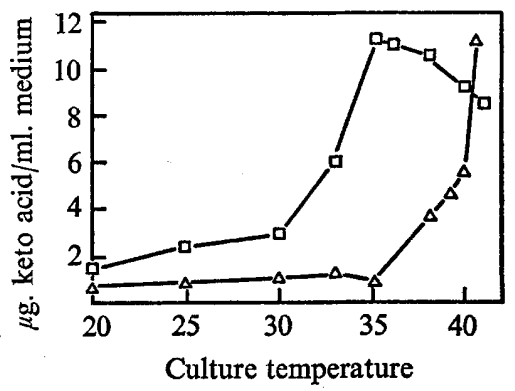

Fig. 2

Fig. I. Plot of reciprocal of specific growth rate $(\mu)$ against the reciprocal of the glucose concentration for a series of shaken batch cultures of $S$. cerevisiae. Solid line and triangles refer to $25^{\circ}$ cultures, broken line and circles to $38^{\circ}$ cultures. A and B indicate values for $-\mathrm{I} / K_{s}$ from which the values of the saturation constant for 25 and $38^{\circ}$ respectively were calculated. $C$ and $D$ indicate values for maximum specific growth rates for 25 and $28^{\circ}$ respectively. Growth was limited by glucose concentrations which ranged from $O \cdot I$ to 10 mg./ml.

Fig. 2. Levels of $\alpha$-ketoglutarate (square symbols) and pyruvate (triangular symbols) present in the effluent from a glucose-limited chemostat culture of $S$. cerevisiae maintained at various temperatures at a dilution rate of $0 . \mathrm{I} \mathrm{hr}^{-1}$. Glucose concentration in feed $\mathrm{I} 0 \mathrm{mg} . / \mathrm{ml}$.

from the chemostat cultures when equilibrium conditions prevailed and were washed and transferred to Warburg flasks with an excess of glucose as substrate and incubation at $25^{\circ}$. With glucose as growth-limiting substrate in the chemostat and aerobic conditions in the respirometer, the carbon dioxide output was found to be higher as temperature at which the organisms were cultured increased from 25 to $39^{\circ}$ : in contrast, the oxygen uptake remained fairly constant between 25 and $32^{\circ}$ and then fell steadily with increasing temperature (Fig. 3). The respiratory quotient at $25^{\circ}$ was $I \cdot I 5$ but at $39^{\circ}$ it was 8.0 indicating a substantial change in the metabolic pattern of the yeast.

With DL-lactate (15 mg./ml.) as growth-limiting substrate in the chemostat and glucose in excess in the respirometer the oxygen uptake increased as the temperature of the culture was increased from 25 to $34^{\circ}$. With cultures grown at 34 to $39^{\circ}$ the $\mathrm{Q}_{\mathrm{o}_{2}}$ (glucose) declined. When lactate was substituted for glucose in the respirometer the $\mathrm{Q}_{\mathrm{O}_{2}}$ results were generally similar although slightly greater in the range 25 to $35^{\circ}$ (Fig. 4).

In order to determine whether, at higher temperatures, the synthesis of respiratory 
enzymes was inhibited or their activity impaired the following experiments were performed. Yeasts grown in a glucose-limited continuous culture at $25^{\circ}$ were transferred to a respirometer maintained at various temperatures between 22 and $45^{\circ}$. The oxygen uptake increased with temperature up to $42^{\circ}$. Above this temperature (which incidentally, is the maximum permitting growth of the yeast) the respiratory ability fell sharply. This contrasts strongly with the effect of temperature or growth and suggests that it is the synthesis of respiratory enzyme that is inhibited by elevated growth temperatures rather than the activity of the preformed enzymes.

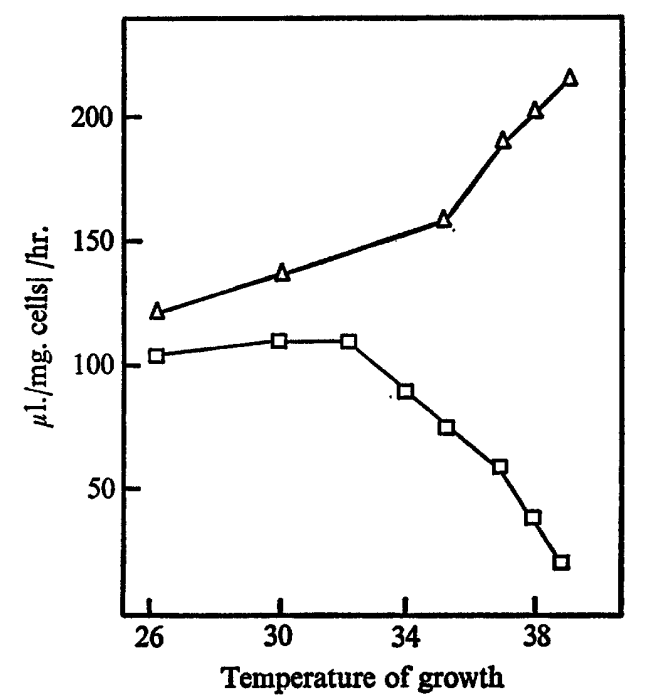

Fig. 3

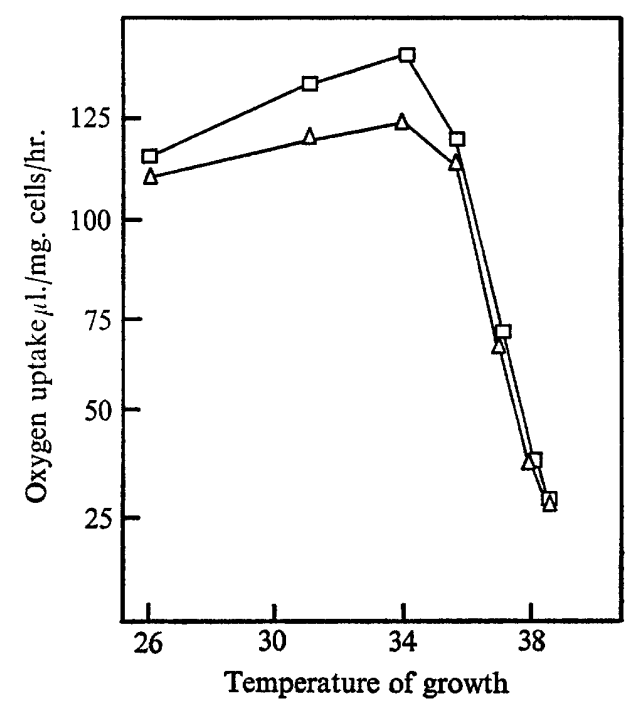

Fig. 4

Fig. 3. Relationship between oxygen uptake (square symbols), carbon dioxide output (triangular symbols) by $S$. cerevisiae and the temperature of growth using continuous culture and a dilution rate of $0.1 \mathrm{hr}^{-1}$. Glucose concentration in the feed was $10 \mathrm{mg} . / \mathrm{ml}$. and growth-limiting. Gas exchange was measured at $25^{\circ}$ after samples of yeasts from the chemostat were withdrawn, washed and placed in Warburg respirometers with glucose as substrate.

Fig. 4. Relationship between oxygen uptake by washed suspensions of $S$. cerevisiae and temperature of growth in continuous culture. Dilution rate was $0.1 \mathrm{hr}^{-1}$, DL-lactate concentration in the feed was $15 \mathrm{mg}$./ $\mathrm{ml}$. and growth-limiting. Gas exchange was measured as for Fig. 3 with glucose (triangular symbols) and lactate (square symbols) as substrate.

\section{Intracellular enzyme and metabolite levels}

A comparison of the enzyme complements of yeast cells grown at 25 and $38^{\circ}$ (Table 3) revealed little difference, particularly for the enzymes concerned with glycolysis and alcohol production. Yeasts grown at $38^{\circ}$ had a slightly smaller content of TCA cycle enzymes: exceptions were succinate dehydrogenase and fumarate hydratase which were similar in the two types of yeast. Activities of most of the respiratory enzymes measured were slightly greater in the organisms grown at $38^{\circ}$ but succinate: Cytochrome- $c$ oxidoreductase was different in that it was lower.

The greatest differences in enzyme contents were found with enzymes reacting with $\alpha$-ketoglutarate (Table 4). Only one of the enzymes in this group (aspartate: $\alpha$ ketoglutarate aminotransferase) was unaffected by the temperature at which the 
organisms were grown. The enzyme most influenced was $\alpha$-ketoglutarate dehydrogenase; the levels within organisms grown at $25^{\circ}$ were low but the extracts of the organisms grown at $38^{\circ}$ had no detectable activity. The yeast cultured at $38^{\circ}$ had slightly greater levels of $\alpha$-keto acids. Pyruvate and $\alpha$-ketoglutarate were $7 \cdot 5 \pm 0.2$ and $3 . \mathrm{I} \pm 0.2 \mathrm{nmole} / \mathrm{mg}$. yeast material. For yeasts grown at $25^{\circ}$ the corresponding values were $5 \cdot 8 \pm 0 \cdot 2$ and $2 \cdot 1 \pm 0 \cdot 2$.

Table 3. Comparison of activities of enzymes associated with glycolysis, alcohol production, tricarboxylic acid cycle and respiratory chain

\section{Enzyme}

Phosphofructokinase

Pyruvate kinase

Pyruvate dehydrogenase enzyme system

Pyruvate decarboxylase

Alcohol dehydrogenase

Aconitate hydratase

Isocitrate dehydrogenase (NAD specific)

Isocitrate dehydrogenase (NADP specific)

Succinate dehydrogenase

Fumarate hydratase

Malate dehydrogenase

NADH oxidase enzyme system

NADH: cytochrome- $c$ oxidoreductase

Cytochrome-c: oxygen oxidoreductase

Succinate: cytochrome- $c$ oxidoreductase

\begin{tabular}{|c|c|}
\hline $\begin{array}{l}\text { Yeasts grown } \\
\text { continuously } \\
\text { at } 25^{\circ}\end{array}$ & $\begin{array}{l}\text { Yeasts grown } \\
\text { continuously } \\
\text { at } 38^{\circ}\end{array}$ \\
\hline $\begin{array}{r}73 \pm 3 \cdot 0(3) \\
6 \cdot I \pm 0.5(3) \\
3 \cdot 0 \pm 0.4(5)\end{array}$ & $\begin{array}{r}77 \pm 3 \cdot 7(3) \\
6 \cdot 3 \pm 0 \cdot 4 \text { (3) } \\
2 \cdot 7 \pm 0 \cdot 3(4)\end{array}$ \\
\hline $\begin{array}{l}734 \pm 5 \cdot 0(4) \\
224 \pm 3 \cdot 7(4) \\
115 \pm 1 \cdot 4(4) \\
6 \cdot 6 \pm 0 \cdot 2(3)\end{array}$ & $\begin{array}{r}509 \pm 4 \cdot 4(4) \\
224 \pm 5 \cdot 7(4) \\
93 \cdot 0 \pm 1 \cdot 7(4) \\
5 \cdot 6 \pm 0 \cdot 3(4)\end{array}$ \\
\hline $15.9 \pm 0.5(4)$ & $12 \cdot 2 \pm 0.5(3)$ \\
\hline $\begin{array}{r}34 \cdot 2 \pm 1 \cdot 0(4) \\
27 \cdot 8 \pm 0.6(3) \\
613 \pm 8 \cdot 0(4) \\
13 \cdot 7 \pm 0 \cdot 3(4) \\
41 \cdot 5 \pm 0.8(3)\end{array}$ & $\begin{array}{r}35 \cdot 7 \pm 0.6(4) \\
28 \cdot 0 \pm 1 \cdot 5(3) \\
517 \pm 3.5(3) \\
16.4 \pm 0.4(4) \\
52.8 \pm 0.5(3)\end{array}$ \\
\hline $18 \cdot 3 \pm 0 \cdot 4(3)$ & $22 \cdot 7 \pm 0.5(3)$ \\
\hline $12 \cdot I \pm 0 \cdot 2(3)$ & $7.9 \pm 0.2(4)$ \\
\hline
\end{tabular}

Levels of enzyme activities in yeast grown in glucose-limited continuous culture. (Glucose concentration $10 \mathrm{mg} . / \mathrm{ml}$; dilution rate $0^{\circ} \mathrm{I} \mathrm{hr}^{-1}$.) Results are mean values expressed as $\mathrm{m} \mu$ mole substrate utilized $/ \mathrm{min}$./mg. protein \pm S.E.M. The numbers of observations are given in parenthesis.

Table 4. Comparison of activities of enzymes in yeast which involve ketoglutarate as a substrate

\begin{tabular}{|c|c|c|c|}
\hline Enzyme & E.C. number & $\begin{array}{l}\text { Yeasts grown } \\
\text { continuously } \\
\text { at } 25^{\circ}\end{array}$ & $\begin{array}{c}\text { Yeasts grown } \\
\text { continuously } \\
\text { at } 38^{\circ}\end{array}$ \\
\hline $\begin{array}{l}\text { ate dehydrogenase } \\
\text { tem }\end{array}$ & - & $2 \cdot 2 \pm 0 \cdot 4(8)$ & 0.3 \\
\hline $\begin{array}{l}\text { AD oxidoreductase } \\
\text { TADP oxidoreductase }\end{array}$ & $\begin{array}{l}\text { I. } 4.1 .2 / 3 . \\
1.4 .1 .3 / 4\end{array}$ & $\begin{array}{r}13.5 \pm 0.3(4) \\
668 \pm 8.2(4)\end{array}$ & $\begin{array}{r}27 \cdot 5 \pm 0 \cdot 3(3) \\
532 \pm 7 \cdot 6(4)\end{array}$ \\
\hline $\begin{array}{l}\text { toglutarate } \\
\text { sferase }\end{array}$ & 2.6.I.I. & $13.7 \pm 0.2(3)$ & $I 3 \cdot I \pm 0 \cdot 3(3)$ \\
\hline
\end{tabular}

Total adenosine phosphate levels for yeasts grown at 38 and $25^{\circ}$ were, respectively, 6.4 and $7 \cdot \mathrm{I} \mathrm{nmole} / \mathrm{mg}$. yeast material. This small difference was reflected in the corresponding values for ATP and AMP; levels of ADP were slightly greater for the $38^{\circ}$ culture. There were no major differences between the levels of NAD at the two 
temperatures and of reduced NAD. In each case the value was in the range $I \cdot I$ and I. 6 nmole/mg. yeast material. NAD:NADH ratios were I $\cdot$ I for yeasts grown at $38^{\circ}$ and $\mathrm{I} \cdot 5$ for those cultured at $25^{\circ}$.

\section{DISCUSSION}

Many reports on the effect of temperature upon micro-organisms are complicated by the fact that not all the other environmental parameters were controlled. This is particularly true for batch culture in which the environment invariably changes continuously, leading to changes in enzymic composition of the organisms. For instance, the level of succinate-cytochrome $\mathrm{C}$ oxidoreductase in yeast cells varied Ioo-fold during growth in a batch culture (Ephrussi, Slonimski, Yotsuyanagi \& Tavlitski, 1956). The effect of temperature on the metabolism of growing organisms is, therefore, more easily studied when they are growing in a constant environment with their growth rate determined by the rate of supply of growth-limiting nutrient; that is, in continuous culture.

The chemical environments provided by the media of the yeast culture growing in glucose-limited chemostat 25 and $38^{\circ}$ were very similar. This was emphasized by the overall constancy in the levels of both the tricarboxylic acid cycle enzymes and the enzymes of the respiratory chain between the cells grown at the two temperatures. However, a marked decrease occurred in the respiratory capacity of the yeast grown at the higher temperature. Yeast grown in lactate-limited cultures was affected to the same extent indicating that the effect was not restricted to organisms metabolizing glucose as the sole carbon source. Neither was the effect due to an enrichment of the population with respiratory-deficient mutants nor to a decrease in viability nor to a significant change in the level of aeration. The decrease in the respiratory capacity of yeast grown at the higher temperature was accompanied by a decrease in yield and by an increase in the amount of ethanol produced. These effects were accompanied by an increase in the levels of $\alpha$-keto acids in the growth medium. With $\alpha$-ketoglutarate the levels rose in that range of culture temperature ( 30 to $35^{\circ}$ ) in which the respiratory capacity began to decline. At growth temperatures above $35^{\circ}$ the level of pyruvate in the medium increased sharply as the respiratory activity continued to fall (compare Fig. 2 with Fig. 3, 4). In contrast the intracellular levels of $\alpha$-keto acids showed a much smaller increase at the higher growth temperature. A similar situation has been reported by Suomalainen \& Ronkainen (1963) for baker's yeast grown first under aerobic and then anaerobic conditions. In their system, despite a considerable increase in the levels of $\alpha$-keto acids in the growth medium, the intracellular levels remained relatively constant.

The increase in the level of pyruvate from $5.8 \mathrm{nmole} / \mathrm{mg}$. in the organisms grown at $25^{\circ}$ to $7.5 \mathrm{nmole} / \mathrm{mg}$. in those grown at $38^{\circ}$ may well favour fermentation without any change in the rate of oxidation of pyruvate. Taking results of Polakis \& Bartley (I965) for internal cell volume, the corresponding internal mean concentrations were about $\mathrm{I} \cdot 9$ and $2.5 \mathrm{~mm}$. Holzer (I96I) reported that a yeast pyruvate oxidase system became saturated at the level of I mM-pyruvate whereas pyruvate decarboxylase was only saturated at $20 \mathrm{~mm}$-pyruvate.

A comprehensive enzymic survey of this yeast revealed that the increased level of $\alpha$-ketoglutarate in the growth medium may be correlated with the level of $\alpha$-ketoglutarate dehydrogenase present in the cells. In cell-free extracts of organisms grown 
at $25^{\circ}$ the activity of this enzyme was low but in extracts of organisms grown at $38^{\circ}$ the level was greatly reduced. Vitols \& Linnane (I96I) also found a low level of this enzyme in a commercial sample of baker's yeast, presumably cultured at temperatures below $25^{\circ}$. Cell-free extracts of their yeast quickly oxidized citrate and pyruvate plus malate but accumulated $\alpha$-ketoglutarate.

It is of interest that one enzyme, NAD-specific glutamate dehydrogenase, showed a significant increase in complement $(100 \%)$ at the higher temperature of culture. In contrast the complement of NADP-specific glutamate dehydrogenase decreased by $20 \%$. Chapman \& Bartley (I968) demonstrated a similar reciprocal relationship between the changes in levels of the two glutamate dehydrogenases of yeast during a change from aerobic to anaerobic conditions. The reason for such a reciprocal relationship is not known but may be related to the intracellular compartmentation of $\alpha$-ketoglutarate. It is suggested that the primary effect on the yeast of the increase in growth temperature was to reduce the level of $\alpha$-ketoglutarate dehydrogenase within the organisms, probably arising from the inhibition of the synthesis of the enzyme by the elevated temperature. The changes in respiratory capacity, metabolite levels and levels of other enzymes were probably of secondary importance but acted to stimulate fermentative metabolism at the higher temperatures of growth.

\section{REFERENCES}

Alvarez, A., VANDERwinkel, E. \& Wiame, J. M. (1958). Oxidation of pyruvic acid in yeast. Biochimica et Biophysica Acta 28, 333.

BergmeYer, H.-U. (1963). Methods of Enzymatic Analysis. New York: Academic Press.

BRown, C. M. \& Hough, J. S. (I965). Elongation of yeast cells in continuous culture. Nature, London 206, 676 .

Brown, C.M. \& Hough, J. S. (1966). Protein-disulphide reductase activity in yeast. Nature, London 2II, 201 .

BRown, H. T. (1914). Some studies on yeast. Annals of Botany 28, 197.

BÜCHER, T. \& REDETSKI, H. (I95I). Eine spezifische photometrische Bestimmung von äthylalkohol auf fermentativem Wege. Klinische Wochenschrift 29, 615.

Chapman, C. \& Bartley, W. (1968). The kinetics of enzyme changes in yeast under conditions that cause the loss of mitochondria. Biochemical Journal 107, 455.

Christopherson, J. (1967). In Molecular Mechanisms of Temperature Adaption. Ed. by Ladd Prosser. American Association for the Advancement of Science, Washington.

Cutrs, N. S. \& RAINBOw, C. (1950). Studies of a yeast exacting towards $p$-aminobenzoic acid. Journal of General Microbiology 4, 150.

Ephrussi, B., Slonimski, P. P., Yotsuyanagi, Y. \& TAVlitski, J. (1956). Variations physiologiques et cytoliques de la levure au cours du cycle de la croissance aerobie. Compte Rendu des Travaux du Laboratoire Carlsberg: Série Physiologique 26, 87.

GiLliLAND, R. B. (1959). Determination of yeast viability. Journal of the Institute of Brewing 65, 424.

Green, D. E. \& ZIEGLER, D. M. (1963). Electron transport particles. Methods in Enzymology 6, 416.

HAUBER, J. \& SinGER, T. P. (1967). Studies on succinate dehydrogenase-intracellular distribution, catalytic properties \& regulation of fumarate reductases in yeasts. European Journal of Biochemistry 3, 107.

HeATLEY, N. G.(1950). A versatile fermentation sampling arrangement. Journalof General Microbiology $4,410$.

Herbert, D., Elsworth, R. \& Telling, R. C. (1956). The continuous culture of bacteria; a theoretical and experimental study. Journal of General Microbiology 14, 601.

Holzer, H. (196I). Regulation of carbohydrate metabolism by enzyme competition. Cold Spring Harbor Symposia on Quantitative Biology 26, 277.

Holzer, H., GaRLACH, V., JACOBI, G. \& GNOTH, M. (1958). Anreicherung und Eigenschaften einer Transaminase aus Bierhefe. Biochemische Zeitschrift 329, 529. 
Holzer, H. \& Goedde, H. W. (1957). Oxydation von $\alpha$-Ketosauren und einigen Aldehyden mit Pyruvat-decarboxylase aus Hefe. Biochemische Zeitschrift 329, 192.

Holzer, H., HIERHOlZER, G. \& WITT, I. (1963). $\alpha$-Ketoglutaratoxydase der Hefe. Biochemische Zeitschrift 337, 115 .

Holzer, H. \& SCHNEIDER, S. (1957). Anreicherung und Trennung einer D.P.N.--spezifischen und einer T.P.N.-spezifischen Glutaminsäure-dehydrogenase aus Hefe. Biochemische Zeitschrift 329, 361 .

Hough, J. S. \& RudiN, A. D. (1958). Experimental production of beer by continuous fermentation. Journal of the Institute of Brewing 64, 404.

Hough, J. S. \& Stevens, R. (196r). Beer flavour. IV. Factors affecting the production of fusel oil. Journal of the Institute of Brewing 67, 488.

KNox, R. (1955). The effect of temperature on enzymic adaptation, growth and drug resistance. Symposium of the Society for General Microbiology 3, I 84 .

KorNBERG, A. (I955a). Isocitric dehydrogenase of yeast (TPN). Methods in Enzymology 1, 705.

KorNBerg, A. (1955b). Isocitric dehydrogenase of yeast (DPN). Methods in Enzymology 1, 707.

Lindegren, C. C. (1949). The Yeast Cell, its Genetics and Cytology. St. Louis: Education Publishers.

Linnane, A. W., Biggs, D. R., Huang, M. \& Clark-Walker, G. D. (I968). The effects of chloramphenicol on the differentiation of the mitochondrial organelle. In Aspects of Yeast Metabolism. Ed. by A. K. Mills and H. Krebs, p. 222. Oxford: Blackwell.

Lowry, O. H., Rosebrough, N. J., Farr, A. L. \& Randall, R. J. (I95I). Protein measurement with the Folin phenol reagent. Journal of Biological Chemistry 193, 265.

Mackler, B., Collip, P. J., Appajt-Rao, N., Duncan, H. M. \& Huennekens, F. M. (I962). An electron transport particle from yeast: purification \& properties. Journal of Biological Chemistry 237, 2968.

Ogur, M., ST. John, R. \& NAGAI, S. (I957). Tetrazolium overlay technique for population studies of respiration deficiency in yeast. Science, New York $125,928$.

Polakis, E. S. \& BartLey, W. (I965). Changes in the enzyme activities of $S$. cerevisiae during aerobic growth on different carbon sources. Biochemical Journal 97, 284.

Polakis, E. S., BartLey, W. \& MeEK, G. A. (1964). Changes in the structure and enzyme activity of $S$. cerevisiae in response to changes in the environment. Biochemical Journal 9o, 369.

RACKER, E. (1950). Spectrophotometric measurement of the enzymic formation of fumaric and cisaconitic acids. Biochimica et Biophysica Acta 4, 21 I.

Rose, I. A. (1960). Studies on the enolization of pyruvate by pyruvate kinase. Journal of Biological Chemistry 235, 1170.

ShultZ, A. S. \& ATKIN, E. (1947). The utility of bios response in yeast classification and nomenclature. Archives of Biochemistry 14, 369.

Sulebele, G. A. \& Rege, D. V. (1967). Temperature sensitivity of catalase induction in S. cerevisiae. Enzymologia 33, 354 .

Suomalainen, H. \& Ronkainen, P. (1963). Keto-acids in bakers yeast and in fermentation solution. Journal of the Institute of Brewing 69, 478.

Tempest, D. W. \& HerberT, D. (1965). Effect of dilution rate and growth limiting substrate on the metabolic activity of Torula utilis cultures. Journal of General Microbiology 4x, I43.

Viñuela, E., Salas, M. L. \& Sols, A. (1963). End product inhibition of yeast phosphofructokinase by ATP. Biochemical and Biophysical Research Communications I2, I40.

VItols, E. \& Linnane, A. W. (I961). Studies on the oxidative metabolism of S. cerevisiae. Journal of Cell Biology 9, 701.

Wolter, H., LieTZ, P. \& Beubler, A. (I966). Influence of temperature and yeast strain on the formation of amyl alcohol, isobutanol and ethyl acetate in fermenting malt wort. Folia Microbiologica, Praha II, 2 IO.

Wickerham, L. J. (195I). Taxonomy of Yeasts. Bulletin. United States Department of Agriculture No. I029. 